\title{
Surviving Probability Indicators of Landing Juvenile Magellanic Penguins Arriving Along the Southern Brazilian Coast
}

\author{
Sandra Carvalho Rodrigues ${ }^{1,2}$, Andréa Corrado Adornes ${ }^{2}$, Euclydes Antônio dos Santos \\ Filho $^{1}$, Rodolfo Pinho Silva Filho ${ }^{2,3}$, Elton Pinto Colares ${ }^{1 *}$ \\ ${ }^{1}$ Instituto de Ciências Biológicas; Universidade Federal do Rio Grande; Avenida Itália, km 8; C. P.: 474; 96201 - \\ 900; Rio Grande - RS - Brasil. ${ }^{2}$ Centro de Recuperação de Animais Marinhos; Museu Oceanográfico "Prof. \\ Eliézer de C. Rios"; Universidade Federal do Rio Grande; Rio Grande - RS - Brasil. "3nternational Fund for \\ Animal Welfare; Emergency Relief Team; Oiled Wildlife Division
}

\begin{abstract}
The aim of this work was to monitor and study the hematocrit and weight of juvenile penguins, with and without oil cover, found alive along the southern coast of Brazil, after capture, as well as before eventual death or release. Released juvenile penguins showed higher weight and hematocrit $(3.65 \pm 0.06 \mathrm{~kg}$ and $44.63 \pm 0.29 \%$, respectively) than those that died $(2.88 \pm 0.08 \mathrm{~kg}$ and $34.42 \pm 1.70 \%$, respectively). Penguins with higher hematocrit and weight after capture had higher mean weight gain than their counterparts with smaller hematocrit and weight after the capture. Besides, juveniles with higher hematocrit and weight after the capture had higher survival rates, independent of the presence or absence of oil. The results suggested that juveniles covered with oil might have been healthier than the juveniles without oil. The animals without oil probably died as a consequence of health disturbances, while the animals with oil possibly were healthy before contact with oil in the sea.
\end{abstract}

Key words: disease, survival, oil, hematocrit, body weight, Spheniscus magellanicus

\section{INTRODUCTION}

Magellanic penguins, Spheniscus magellanicus, are found in both, Pacific and Atlantic oceans, along the southern South American coast and nearby islands (Boersma et al., 1990). They breed along these coasts, as well as on the Falkland Islands $\left(54^{0} \mathrm{~S}\right)$ (Williams and Boersma, 1995). Magellanic penguins are pelagic during fall and winter (May- August). Populations that breed along the east coast of Argentina (Atlantic coast) migrate to the Brazilian coast. They start returning to their colonies during late August or early September, and migrate again towards north in March and April (Boersma et al., 1990; Williams and Boersma, 1995).

Migration is a challenging period for penguins, especially for juveniles, which face their first migration. There are several threats to penguins' populations, including climatic changes, commercial fishing, marine oil pollution and garbage, especially plastic such as cans and bottles (Boersma and Stokes, 1995; Petry and Fonseca, 2002). Oil pollution is an important

*Author for correspondence: ecolares @ octopus.furg.br 
cause of mortality for almost all the temperatezone penguin species (Boersma and Stokes, 1995), and it is estimated to cause the death of 42,000 Magellanic penguins each year along the southern coast of Argentina alone (Gandini et al., 1994). This contamination can occur by oil contact with plumage, oil ingestion when the animals feed, or through preening (Rattner, 1981; Briggs et al., 1996; U.S. Environmental Protection Agency and Office of Emergency and Remedial Response, 1999). Petroleum toxicity may cause some general disturbances in wild birds, including hypothermia, dehydration, gastrointestinal problems, pneumonias, hemolytic anemia (Tseng, 1993), and immune system damage (Briggs et al., 1996).

Besides oil contamination, it is also known that starvation, when combined with endoparasite burdens, contribute to the mortality of penguins (Clarke and Kerry, 1993). These factors may be more impacting when associated to a body temperature decrease observed during fasting (Mata et al., 2001), which could lead to an increase in energy demand, then stimulating the penguins to leave the water and becoming anemic afterwards (Tseng, 1993).

Blood analysis, in combination with other diagnostic methods, allows to asses the health of individuals and to identify the organs/systems affected by infectious diseases, nutritional deficiencies and other health problems (Newman et al., 1997). Some studies have described an association between the hematocrit and health and nutritional status (Villegas et al., 2002). Hematocrit is a fairly good measure of the relative number of erythrocytes in the blood, being indicative of anemia (small values of hematocrit) and dehydration (high values of hematocrit) (Campbell, 1994; Merino and Barbosa, 1997). Body mass is another important index for monitoring the health status of animals. According to Oka and Okuyama (2000), body mass is highly correlated with organ masses and lipid deposits. Therefore, body mass is an effective index to evaluate the nutritional status of birds (Oka and Okuyama, 2000).

It has been common to encounter Magellanic penguins along the southern coast of Brazil during winter, including animals that had direct contact with oil (Petry and Fonseca, 2002). Based on the available information, it is believed that the penguins, with or without oil, which reached the beaches, presented different health status, becoming weak by different reasons. In order to investigate the possible health differences between Magellanic penguins arriving on the southern Brazilian coast, with or without oil, hematocrit and body weight of these animals during a recovery attempt at a rehabilitation center were monitored. Besides, the percentage of juveniles, with or without oil, which have survived, or died, at the rehabilitation center, between 1997 and 2003, was also analyzed.

\section{MATERIALS AND METHODS}

Juvenile Magellanic penguins (identified through plumage pattern, according to Williams and Boersma, 1995) were caught along the southern Brazilian coast (between $33^{\circ} 44^{\prime} \mathrm{S}$; $053^{\circ} 22^{\prime} \mathrm{W}$ and $31^{0} 21^{\prime} \mathrm{S}$; $\left.051^{\circ} 02^{\prime} \mathrm{W}\right)$, between 2002 and 2003 and transported to the Marine Animals's Recovery Center (CRAM) of the Universidade Federal do Rio Grande, Rio Grande/RS, Brazil (License number 02023002639/97-10 of the Brazilian Environmental Agency - Instituto Brasileiro do Meio Ambiente e dos Recursos Naturais Renováveis). Blood was collected from the metatarsal medial vein, using $25 \times 8$ needles, right after the animals were brought to CRAM, as well as at eventual death or release. Samples were immediately put into a heparinized microcapillary tube and the hematocrit then determined by the microhematocrit method. Juvenile penguins were weighed in a digital scale (Toledo Prix S, accurate $5 \mathrm{~g}$ ) after blood sampling.

Penguins with oil received a single dose of activated charcoal slurry administered by gavage, at a dosage of $200 \mathrm{mg} / \mathrm{kg}$ body weight, as soon as they arrived at the rehabilitation center in order to reduce the gastrointestinal toxic effects caused by ingested oil. All penguins ingested mineral water, also administered by gavage, fed fish, and received a dose of vermifuge, as explained in the protocol of Ruoppolo et al. (2004). Oiled penguins were washed to remove the oil from plumage only after a good health status (Ruoppolo et al., 2004). The number of penguins found with or without oil along the sourthern Brazilian coast which survived, or died, at the rehabilitation center between 1997 and 2003 were also analized.

The Two-way ANOVA, followed by a Tukey's multiple range test, was employed to investigate 
the statistical differences between the first and last hematocrit and weight values, between and within the groups. The level of significance adopted was 0.05 .

\section{RESULTS}

Survival/mortality of juveniles with and without oil $(1997$ - 2003)

The percentage of juvenile Magellanic penguins with oil was higher than the percentage of penguins without oil. In addition, the percentage of mortality was higher for penguins without oil, while rehabilitation success was higher for penguins with oil (Table 1).

\section{Weight}

All the juvenile birds presented first weight significantly smaller than the last one $(\mathrm{p}<0.05)$. However, surviving juveniles, with or without oil, had first and last weight significantly higher than the juveniles that died $(p<0.05)$ (Table 2). Mean weight $( \pm$ SE) of surviving juveniles with oil $(\mathrm{n}=87)$ or without oil $(\mathrm{n}=5)$ was $2.75 \pm 0.05 \mathrm{~kg}$ and $2.59 \pm 0.11 \mathrm{~kg}$ at arrival, respectively, showing a median weight gain of $32.55 \%$ and $45.17 \%$ along rehabilitation (Table 2). Juveniles with oil $(\mathrm{n}=18)$ or without oil $(n=12)$ which died presented first weight of $2.38 \pm 0.06 \mathrm{~kg}$ and $2.37 \pm 0.11 \mathrm{~kg}$, respectively, with an increase of only $24.13 \%$ and $17.48 \%$ during the recovery attempt (Table 2).

Table 1 - Survival/mortality of juvenile Magellanic penguins, with and without oil, found alive along the beach (southern Brazil) between 1997 and 2003.

\begin{tabular}{lcccc}
\hline Juveniles & $\boldsymbol{\%}$ & $\boldsymbol{n}$ & With oil (\%) & Without oil (\%) \\
\hline Total & 100 & 358 & 59.50 & 40.50 \\
Released & 64.80 & 232 & 70.89 & 55.86 \\
Dead & 35.20 & 126 & 29.11 & 44.14 \\
\hline
\end{tabular}

Table 2 - Mean first and last weight $( \pm$ SE) values $(\mathrm{kg})$ and weight gain $(\%)$ of juvenile Magellanic penguins. JWR $=$ juveniles collected without oil and released; JWD $=$ juveniles collected without oil that died; JOR = juveniles collected with oil and released; JOD = juveniles collected with oil that died.

\begin{tabular}{lcccc}
\hline Juveniles & $\boldsymbol{N}$ & First weight & Last weight & Weight gain (\%) \\
\hline JWR & 5 & $2.586 \pm 0.11^{\mathrm{a}}$ & $3.754 \pm 0.27^{\mathrm{b}}$ & 45.17 \\
JWD & 12 & $2.368 \pm 0.11^{\mathrm{c}}$ & $2.782 \pm 0.13^{\mathrm{a}}$ & 17.48 \\
JOR & 87 & $2.750 \pm 0.05^{\mathrm{a}}$ & $3.645 \pm 0.07^{\mathrm{b}}$ & 32.55 \\
JOD & 18 & $2.375 \pm 0.06^{\mathrm{c}}$ & $2.948 \pm 0.09^{\mathrm{a}}$ & 24.13 \\
\hline abc Equal letters indicate homogeneous groups (ANOVA, $p>0.05)$ & &
\end{tabular}

\section{Hematocrit}

Juveniles without oil which were eventually released $(n=5)$ presented similar values of hematocrit (mean \pm SE) at first and last samples $(43.00 \pm 1.79 \%$ and $43.40 \pm 0.98 \%$, respectively; $p$ $>0.05)$. However, the animals with oil presented first hematocrit $(\mathrm{n}=107 ; 47.48 \pm 0.54 \%)$ significantly:higher than animals without oil $(\mathrm{n}=19 ; 38.37 \pm 1.34 \% ; \mathrm{p}<0.05)$, regardless of eventual survival. Both groups of released juveniles, with and without oil, had last hematocrit values $(n=95 ; 44.63 \pm 0.29 \%)$ within the normal hematocrit known for this species (42 $\pm 4 \%$, Hawkey et al., 1989) (Table 3). Juveniles without oil which died during the treatment $(n=14)$ showed also similar values of hematocrit at first and last samples $(36.71 \pm 1.49 \%$ and $33.50 \pm 2.77 \%$, respectively; $p>0.05)$. However, these values were smaller than those of released juveniles $(\mathrm{p}<$ 0.05). Juveniles, with or without oil, which died during the treatment had last hematocrit significantly smaller $(\mathrm{n}=31 ; 34.42 \pm 1.70 \% ; \mathrm{p}<$ 0.05 ) than the surviving penguins (Table 3 ). 
Table 3 - Mean first and last hematocrit ( \pm SE) values $(\%)$ of juvenile Magellanic penguins. JWR = juveniles collected without oil and released; JWD $=$ juveniles collected without oil that died; JOR $=$ juveniles collected with oil and released; JOD $=$ juveniles collected with oil that died.

\begin{tabular}{lccc}
\hline Juveniles & $\boldsymbol{N}$ & First hematocrit & Last hematocrit \\
\hline JWR & 5 & $43.00 \pm 1.79^{\mathrm{a}}$ & $43.40 \pm 0.98^{\mathrm{a}}$ \\
JWD & 14 & $36.71 \pm 1.49^{\mathrm{b}}$ & $33.50 \pm 2.77^{\mathrm{b}}$ \\
JOR & 90 & $47.52 \pm 0.57^{\mathrm{c}}$ & $44.70 \pm 0.30^{\mathrm{a}}$ \\
JOD & 17 & $47.23 \pm 1.66^{\mathrm{c}}$ & $35.18 \pm 2.15^{\mathrm{b}}$ \\
\hline
\end{tabular}

${ }^{\mathrm{abc}}$ Equal letters indicate homogeneous groups (ANOVA, $p>0.05$ ).

\section{DISCUSSION}

A great problem to juvenile Magellanic penguins is starvation. It has been suggested by Gandini et al. (1994) that starvation was the most important cause of death for fledglings along the coast of Chubut (Argentina). Fasting occurs because food is unavailable, or because there may be other significant activities, such as moult, migration or reproduction (Groscolas and Robin, 2001), or as a consequence of oil contact (Culik et al., 1991; Tseng, 1993). Gandini et al. (1994) observed a weight decrease in dead Magellanic penguins found along the coast of Chubut. Most dead birds, whether they were oiled or not, were emaciated, had empty stomachs, and little or no subcutaneous fat. In a similar way, independent of the presence or absence of oil, juvenile Magellanic penguins transported to the rehabilitation center had significantly smaller weight at arrival (first weight) than the last weight. In spite that all the animals had increased weight along the rehabilitation period, dead juveniles had first and last weights smaller than the released ones. Additionally, dead juveniles had first weight smaller than the minimal mean weight $(2.62 \mathrm{~kg})$ found in wild Magellanic penguins of about five months old (Boersma et al., 1990), while released juveniles had first weight higher than this minimal mean weight. Thus, first weight could be used as an indicative of the probability of successful recovery.

Treatment at the rehabilitation center was successful for the majority of penguins with oil $(70.89 \%, \mathrm{n}=151)$, contrarily to penguins without oil $(55.86 \%, \mathrm{n}=81)$. In general, juveniles with oil were healthy animals before they contacted oil in the sea. Penguins with oil could leave water as a consequence of oil contact, which causes loss of feather structure, allowing cold water to contact the skin, lowering body temperature (Culik et al., 1991; Tseng, 1993). In order to reduce the energy cost and avoiding hypothermia, the animals leave the water. Besides, penguins at the coast, out of water, don't feed and, thus, their body weight decreases (Tseng, 1993). Petroleum poisoning may also cause intestinal mal-absorption and metabolic abnormalities, both disturbances contributing to weight decrease (Briggs et al., 1996). Once hydrated, fed, and washed at the rehabilitation center the majority of juveniles with oil survived, suggesting that abnormalities only occurred as a consequence of oil.

Another problem faced by penguins in land is the dehydration. Under this situation, penguins do not feed and also do not ingest water and, consequently, dehydrate, since they normally use food and metabolic water for osmotic regulation and loss compensation (Culik and Wilson, 1992; Nagy and Obst, 1992). Dehydration causes the blood to concentrate, resulting in a falsely elevated hematocrit (Tseng, 1993). Oiled birds may also show other disturbances, as regurgitation and diarrhea (Tseng, 1993), associated to a decrease in the absorption of both sodium and water from the gastrointestinal tract, thus further exacerbating dehydration (Crocker et al., 1974). In the present study, this was visible through the first hematocrit values of oiled juveniles, which were high possibly as a consequence of the process, called hemoconcentration (Tseng, 1993). However, according to Tseng (1993), birds reach normal values of hematocrit after hydration. In the present work, this was observed with juveniles that survived. Hydration and other treatment procedures successfully recovered these animals at the rehabilitation center, indicating that they were probably healthy penguins, which became weak because of the contact with oil. Hematocrit at arrival was high, indicating dehydration, but it increased until returning to the normal values for this species during the rehabilitation process. On the other hand, animals with oil that died, had a high decrease in hematocrit from the first to the 
last one. This indicated anemia. Anemia can be caused by oil ingested through preening. This may irritate gastrointestinal mucosa, and subsequently cause hemorrhage (Tseng, 1993), and oxidative damage of hemoglobin, leading to the formation of Heinz bodies and anemia (Leighton et al., 1983). However, according to Tseng (1993), once birds become adequately hydrated and damaged red blood cells are removed from the circulation, hematocrit decreases dramatically. Juveniles with oil that died might already be anemic at arrival. This could occur because, at arrival, red blood cells percentage was small, but coincidently there was a small blood volume, so hematocrit was seemingly high, and anemia was not visible. So, these penguins died afterwards to hydration. They probably were unhealthy animals previous to oil contact, so it would be difficult to survive the consequences of oil contact and some disease concomitantly.

Juveniles with higher hematocrit and weight after the capture survived, independent of the presence or absence of oil, even though the majority of surviving penguins were with oil. These results corroborated with the hypothesis that penguins without oil, in general, were unhealthy, thus arriving on beaches because weakness or some disease, while penguins with oil were healthy before they contacted oil. Juvenile Magellanic penguins face hard environmental conditions, starvation (perhaps because of inefficient prey capture) and biological agents during migration that have not been experienced before. Thus, it would be expected that a large number of them would die in their first migration. In fact, it was estimated that $58 \%$ of Magellanic fledglings die during their first pelagic migration, and it is known that pre-breeding age classes present high mortality rates (Scolaro, 1987). In this work $44.14 \%(n=64)$ of mortality was observed at the rehabilitation center for juveniles without oil, and only $29.11 \%(n=62)$ for juveniles with oil.

Thus, it could be concluded that penguins with and without oil have to be treated differently at recovery centers. In this context, weighing and hematocrit seem to be important tools for the assessment of animals' health in a rehabilitation center, furnishing immediate results, as they are easy and fast to determine. These parameters allow to differentiate between the animals with high and low survival probability, and consequently to choose the right treatment. However, one must be careful in the interpretation of hematocrit values when dealing with oiled animals.

\section{ACKNOWLEDGEMENTS}

This work was supported by Petrobrás Oil Company and IFAW. We thank CRAM team to help in this work.

\section{RESUMO}

O hematócrito e o peso de pingüins juvenis, com e sem óleo, encontrados vivos na costa do sul do Brasil, foram monitorados após sua captura, bem como antes de sua morte ou liberação do centro de reabilitação. Os pingüins juvenis liberados apresentaram o último peso e hematócrito (3.65 \pm $0.06 \mathrm{~kg} \mathrm{e} 44.63 \pm 0.29 \%$, respectivamente) maiores do que os pingüins que morreram (2.88 \pm $0.08 \mathrm{~kg} \mathrm{e} 34.42 \pm 1.70 \%$, respectivamente). Pingüins juvenis com maior hematócrito e peso após a captura tiveram maior ganho médio de peso do que os pingüins com menor hematócrito e peso após a captura. Além disso, os juvenis com maior hematócrito e peso após a captura tiveram maiores taxas de sobrevivência, independente da presença ou ausência de óleo. Os resultados sugerem que os pingüins juvenis com óleo poderiam estar mais saudáveis do que os juvenis sem óleo. Os animais sem óleo provavelmente morreram em decorrência de doenças, endoparasitas ou outros distúrbios. Por outro lado, os animais com óleo possivelmente estavam mais saudáveis antes do contato com o óleo no mar.

\section{REFERENCES}

Boersma, P.D., Stokes, D.L. and Yorio, P.M. (1990), Reproductive variability and historical change of Magellanic penguins (Spheniscus magellanicus) at Punta Tombo, Argentina. In-Penguin Biology, ed. L. S. Davis and J.T. Darby. Academic Press, San Diego, pp.15-43

Boersma, P.D. and Stokes, D.L. (1995), Conservation: threats to penguin populations. In-The penguins (Bird families of the world), ed. C.M. Perrins, W.J. Bock and J. Kikkawa. Oxford University Press, New York, pp 127-139 
Briggs, K.T., Yoshida, S.H. and Gershwin, M.E. (1996), The influence of petrochemicals and stress on the immune system of seabirds. Regulatory Toxicology and Pharmacology, 23, 145-155

Campbell, T.W. (1994), Hematology. In-Avian Medicine: Principles and Application, ed. B.W. Ritchie, G.J. Harrison and L.R. Harrison. Wingers Publishing Inc, Lake Worth, Florida, pp 176-198

Clarke, J.R. and Kerry, R.K. (1993), Diseases and parasites of penguins. Korean Journal of Polar Research, 4, 79-96

Crocker, A.D., Cronshaw, J. and Holmes, W.N. (1974), The effect of a crude oil on intestinal absorption in ducklings (Anas platyrhynchos). Environmental Pollution, 7, 165-177

Culik, B.M., Wilson, R.P., Woakes, A.T. and Sanudo, F.W. (1991), Oil pollution on Antartic penguins: effects on energy metabolism end physiology. Marine Pollution Bulletin, 22, 388-391.

Culik, B.M. and Wilson, R.P. (1992), Field metabolic rates of instrumented adelie penguins using doublelabeled water. Journal of Comparative Physiology B, 162, 567-573

Gandini, P., Boersma, P.D., Frere, E., Gandini, M., Holik, T. and Lichtschein, V. (1994), Magellanic penguins (Spheniscus magellanicus) affected by chronic petroleum pollution along coast of Chubut, Argentina. Auk, 111, 20-27

Groscolas, R. and Robin, J. (2001), Long-term fasting and re-feeding in penguins. Comparative Biochemistry and Physiology A, 128, 645-655

Hawkey, C.M., Horsley, D.T. and Keymer, I.F. (1989), Haematology of wild penguins (Sphenisciformes) in the Falkland Islands. Avian Pathology, 18, 495-502

Leighton, F.A., Peakall, D.B. and Butler, R.G. (1983), Heinz-body hemolytic anemia from the ingestion of crude oil: a primary toxic effect in marine birds. Science, 220, 871-873

Mata, A.J., Caloin, M., Michard-Picalemot, D., Ancel, A. and Le Maho, Y. (2001), Are non-migrant white storks (Ciconia ciconia) able to survive a coldinduced fast? Comparative Biochemistry and Physiology A, 130, 93-104

Merino, S. and Barbosa, A. (1997), Haematocrit values in chinstrap penguins (Pygoscelis antarctica): variation with age and reproductive status. Polar Biology, 17, 14-16

Nagy, K.A. and Obst, B.S. (1992), Food and energyrequirements of adelie penguins (Pygoscelis adeliae) on the Antarctic Peninsula. Physiological Zoology, 65 ,

1271-1284 significance and clinical importance. Colonial Waterbirds, 20, 492-504

Oka, N. and Okuyama, M. (2000), Nutritional status of dead oiled rhinoceros auklets (Cenorhinca monocerata) in the southern Japan Sea. Marine Pollution Bulletin, 40, 340-347

Petry, M.V. and Fonseca, V.S.S. (2002). Effects of human activities in the marine environment on seabirds along the coast of Rio Grande do Sul, Brazil. Ornitologia Neotropical, 13, 137-142

Rattner, B.A. (1981), Tolerance of adult mallards to subacute ingestion of crude petroleum oil. Toxicology Letters, 8, 337-342

Ruoppolo, V., Adornes, A.C., do Nascimento, A.C. and Silva-Filho, R.P. (2004), Reabilitação de pingüins afetados por petróleo. Clínica Veterinária, 51, 78-83

Scolaro, J.A. (1987), A model life table for Magellanic penguins (Spheniscus magellanicus) at Punta Tombo, Argentina. Journal of Field Ornithology, 58, 432-441

Tseng, F.S. (1993), Care of oiled seabirds: A veterinary perspective. Abstract presented at Oil Spill Conference, ed. J. Ludwigson. American Petroleum Institute, Washington, DC, pp. 421-424

United States Environmental Protection Agency (EPA) and Office of Emergency and Remedial Response. (1999), Understanding oil spills and oil spill response - Understanding oil spills in freshwater environments. Oil Program Center, EPA publication

Villegas, A., Sánchez, J.M., Costillo, E. and Corbacho, C. (2002), Blood chemistry and haematocrit of the black vulture (Aegypius monachus). Comparative Biochemistry and Physiology A, 132, 489-497

Williams, T.D. and Boersma, P.D. (1995), Magellanic penguins. In-The Penguins (Bird families of the world), ed. C.M. Perrins, W.J. Bock, J. Kikkawa. Oxford University Press, New York, pp.

Newman, S.H., Piatt, J.F. and White, J. (1997), Hematological and plasma biochemical reference ranges of Alaskan seabirds: their ecological 